\title{
Jarosław Karzarnowicz, Funkcje i użycie przypadków w cerkiewnosłowiańskim „Apostole” $z$ Biblioteki Śląskiej, Wydawnictwo Uniwersytetu Gdańskiego, Gdańsk 2008, ss. 182
}

Autor recenzowanej książki przygotował ją do druku jako książkę habilitacyjną ${ }^{2}$.

Omawiana praca ma 182 strony, z czego tekst zasadniczy to 143 strony, bibliografia - 2,5 strony, a 25 stron to indeks form rzeczowników omawianych w książce. Jedna strona zawiera streszczenie w języku angielskim, półtorej - streszczenie w języku rosyjskim. Na ostatnich dwóch stronach (181-182) umieszczono Spis rzeczy.

Przedmiotem opracowania jest średniowieczny manuskrypt ze zbiorów Biblioteki Śląskiej - Apostoł, sygn. R 182 III, dla którego autor używa często określenia Śląski Apostot.

Zacznijmy lekturę książki od zamieszczonych w niej streszczeń w języku angielskim i rosyjskim oraz od Wstęu.

${ }^{1}$ Za konsultacje w trakcie przygotowywania niniejszej recenzji bardzo dziękuję Pani Barbarze Maresz z Działu Zbiorów Specjalnych Biblioteki Śląskiej w Katowicach, Pani dr Weronice Pawłowicz za cenne wskazówki dotyczące księgozbioru księdza Pawła Szymańskiego, a także za pomoc przy ustalaniu filigranów i udostępnione zdjęcia odpowiednich kart zabytku. Pani Jolancie Dobryńczuk z Wojewódzkiej Biblioteki Publicznej im. H. Łopacińskiego w Lublinie dziękuję za podarowany mi artykuł jej autorstwa (Księgozbiór Pawła Szymańskiego odziedziczony przez unickie seminarium w Chetmie, ,Rocznik Chełmski” 1995, t. 1) i wskazówki do moich dalszych studiów w tym temacie. Pani Virze Fris z Ukraińskiego Uniwersytetu Katolickiego we Lwowie i Pani Lidii Snicarčuk z Lwowskiej Narodowej Biblioteki Ukrainy im. V. Stefanyka dziękuję bardzo za konsultacje.

2 Jest to informacja ze stron internetowych Nauki Polskiej: Karzarnowicz od 1 marca 2002 roku do wydania recenzowanej książki korzystał z grantu BW 4500-5-173-2, http:// nauka-polska.pl/dhtml/raporty/praceBadawcze?rtype=opis\&lang=pl\&objectId=36165 [dostęp: 23.07.2011]. 
W streszczeniu w języku angielskim (s. 178) podano takie informacje o tytułowym rękopisie:

1),,[... S Silesian Apostle and Fiodorov's Apostle were in close relationship"3,

2) „The Silesian Apostle is a copy of Fiodorov's Apostle”.

Są to merytorycznie sprzeczne ustalenia, ponieważ w odniesieniu do tekstologii zabytków nie stosujemy wymiennie określeń „close relationship” i „,copy”. Zabytek może być albo jednym, albo drugim.

W tym samym streszczeniu autor podaje, że porównał Ślaski Apostoł z Lwowskim Apostołem Fiodorowa drukowanym w 1574 roku i z trzynastowiecznym Matičinym Apostołem. Jednak w Bibliografii (s. 149-151) nie znajdziemy danych żadnego z tych zabytków, ani też nazwisk badaczy czy wydawców któregokolwiek z nich. Tymczasem na przykład Matičin Apostoł był wydany, co łatwo znaleźć u Hansa Borkenta w Bibliographie linguistique de l'année 1983 et complément des années précédentes (Springer 1985, pozycja 10632, dostępna online). Znane jest też wydanie R. Kovačevićia - The Apostolos of Matica Srpska (13th century) (Belgrade 1979). Z kolei Lwowski Apostot Fiodorowa jest w całości dostępny online pod adresem Ukraińskiej Biblioteki Narodowej: http://www.nbuv.gov.ua/books/rarity/apostol/.

W streszczeniu w języku rosyjskim (s. 179) tytuł recenzowanej tu książki nie odpowiada ani tytułowi polskiemu, ani tytułowi w streszczeniu angielskim. Oto porównanie:

\begin{tabular}{|l|l|l|}
\hline \multicolumn{1}{|c|}{ Polski tytuł } & \multicolumn{1}{c|}{ Angielski tytuł } & \multicolumn{1}{c|}{ Rоsyjski tytuł } \\
\hline Funkcje i użycie przypadków & The system of Noun cases & Система падежей \\
\hline $\begin{array}{l}\text { w cerkiewnosłowiańskim } \\
\text { Apostole }\end{array}$ & $\begin{array}{l}\text { in Church Slavonic } \\
\text { Manuscript Apostle }\end{array}$ & $\begin{array}{l}\text { церковнославянского } \\
\text { рукописного Апостола }\end{array}$ \\
\hline z Biblioteki Śląskiej & from the Silesian Library & $\begin{array}{l}\text { из Силезианской (sic!) } \\
\text { библиотеки в Катовицах }\end{array}$ \\
\hline
\end{tabular}

Treści angielskiego i rosyjskiego streszczenia w ogóle nie odpowiadają sobie, co znaczy, że różne polskie wersje streszczenia były podstawą obu przekładów. Nie można bowiem inaczej wyjaśnić na przykład tego, że w streszczeniu rosyjskim nie ma twierdzenia zawartego w streszczeniu angielskim, że Ślaski Apostoł jest kopią Lwowskiego Apostoła Fiodorowa. W streszczeniu rosyjskim mamy inne twierdzenie (merytorycznie nieprawdziwe i dodatkowo niezręczne stylistycznie): Śląski Apostoł jest „списком с которого (z «Apostoła» Fiodorowa) по мнению некоторых” (s. 179). Następnie autor stwierdza, że Apostoł Fiodorowa i Ślaski Apostoł „Роднит их главным образом отношение к греческому первоисточнику” (s. 179). W ten

\footnotetext{
${ }^{3}$ Wszystkie wyróżnienia w cytatach - jeśli nie zaznaczono inaczej - H.W.
} 
sposób Karzarnowicz zaprzecza samemu sobie: Śląski Apostoł nie może być kopią Apostoła Fiodorowa, skoro oba zabytki coś zaledwie „роднит”, сzyli „zbliża”. W książce próżno jednak szukać informacji z jakiego „греческого первоисточника" autor korzystał - w Bibliografii nie podano „греческого первоисточника".

Przejdźmy do Wstępu. Tutaj Karzarnowicz określa Śląski Apostoł jako będący odpisem Apostoła Fiodorowa z roku 1574 (s. 11). Mamy więc w książce habilitacyjnej trzy różne opinie autora o tym, czym jest badany przez niego rękopis: jest „odpisem”, „is a copy” (streszczenie angielskie), jest „списком [...] по мниению некоторых" (streszczenie rosyjskie). Nie dowiadujemy się więc, jaka jest ostatecznie relacja Ślaskiego Apostoła i Apostoła Fiodorowa.

Poniżej zamieszczam obok siebie karty obu zabytków - nawet niespecjalista dostrzeże widoczne różnice, wykluczające pojęcie kopii, czy choćby odpisu. Poziomą kreską na zdjęciach kart zaznaczyłam miejsce końca tekstu na stronie Apostoła Fiodorowa (lewa karta) w odniesieniu do strony Śląskiego Apostoła (zob. il. 1 i 2).

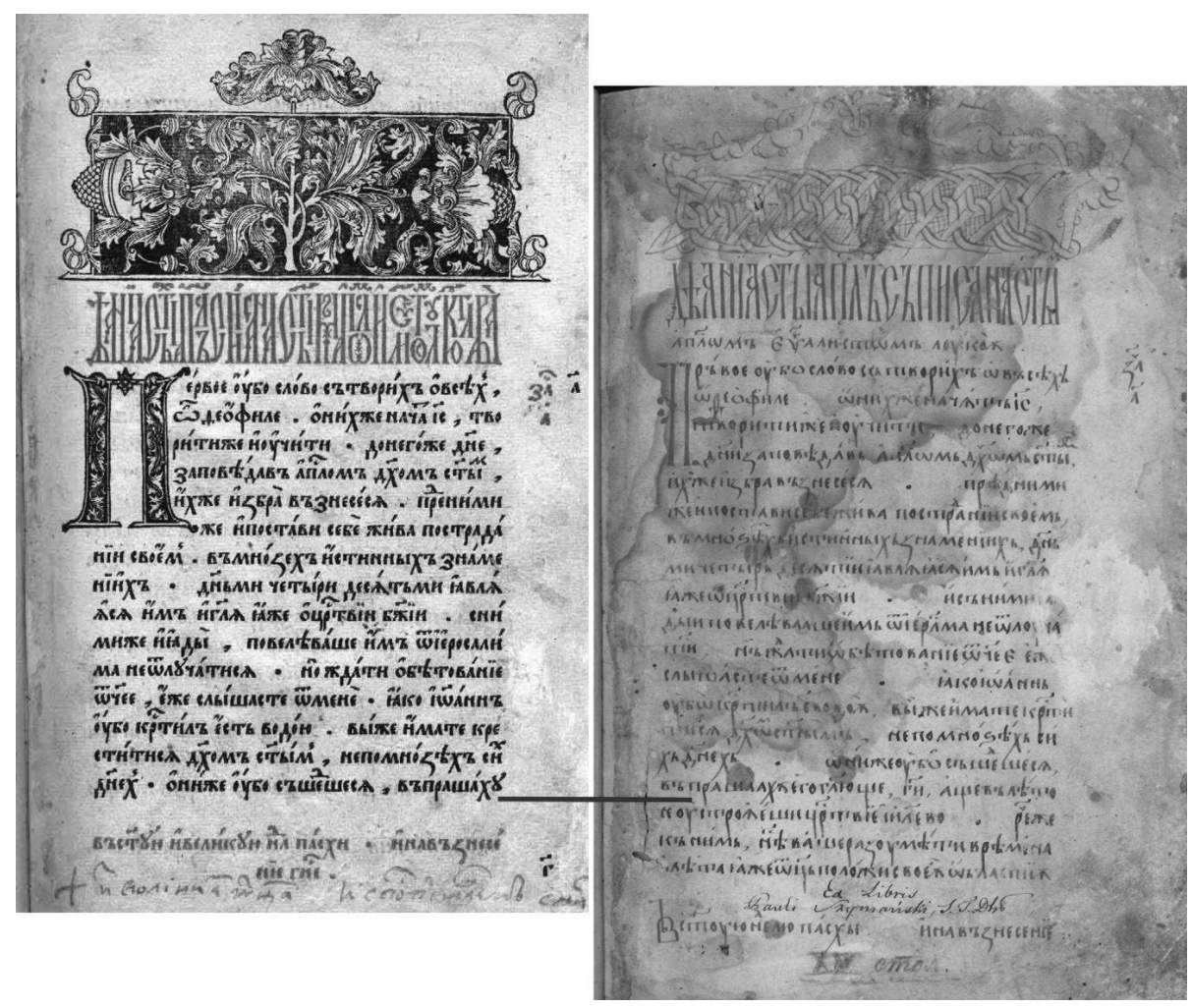

Il. 1. Apostol Fiodorowa z 1574 roku

Il. 2. Apostoł z Biblioteki Śląskiej 
Informacje autora o zabytku we Wstepie i obu streszczeniach charakteryzuje, jak widzimy, nierzetelność, wręcz dezinformacja naukowa.

Niespełna sześciostronicowy Wstęp książki został podzielony na cztery części: 1 . Cel pracy $i$ założenia teoretyczne $-2,5$ strony, 2. Stan badań1,5 strony, 3. Opis zabytku - 1 strona i 4. Zasady doboru materiału - niecała strona.

Część pierwsza Wstępu nosi znamiona ukrytego plagiatowania, czyli niejawnych zapożyczeń koncepcji, myśli i sformułowań. Chodzi tu o wykorzystanie Wstępu Elżbiety Tabakowskiej do książki Brygidy Rudzkiej-Ostyn Z rozważań nad kategoria przypadka (Kraków 2000). Jarosław Karzarnowicz nigdzie w swojej pracy ani nie cytuje, ani nawet nie wspomina Elżbiety Tabakowskiej i jej Wstępu. Książka Brygidy Rudzkiej-Ostyn jest mu znana, umieścił ją w Bibliografii. Oto porównanie, które ilustruje, w mojej opinii, plagiat:

\begin{tabular}{|c|c|}
\hline Wstęp Karzarnowicza & Wstęp Tabakowskiej \\
\hline $\begin{array}{l}\text { „w języku wszystko jest symboliczne, wszyst- } \\
\text { ko jest obdarzone znaczeniem, w tym także } \\
\text { morfemy gramatyczne - wykładniki form } \\
\text { przypadków w językach fleksyjnych” (s. 5) }\end{array}$ & $\begin{array}{l}\text { „gramatyka ma charakter z natury symbolicz- } \\
\text { ny: wszystko, a więc także morfemy grama- } \\
\text { tyczne, które są wykładnikami przypadków } \\
\text { w takich językach jak język polski, ma okre- } \\
\text { ślone znaczenie” (s. 12) }\end{array}$ \\
\hline $\begin{array}{l}\text { „Odżywa tu ponownie znany podział wszyst- } \\
\text { kich przypadków na konkretne - pełniące } \\
\text { funkcje semantyczne, i gramatyczne” (s. 5) }\end{array}$ & $\begin{array}{l}\text { „Cześć pierwsza zawiera zwięzłą analizę } \\
\text { wcześniejszych propozycji opisu kategorii } \\
\text { przypadka [...] przez podział na przypadki } \\
\text { gramatyczne i konkretne” (s. 13) }\end{array}$ \\
\hline $\begin{array}{l}\text { „O kategorii przypadka napisano już wiele } \\
\text { stron” (s. 6) }\end{array}$ & $\begin{array}{l}\text { „Na temat kategorii przypadka napisano bar- } \\
\text { dzo wiele” (s. 10) }\end{array}$ \\
\hline $\begin{array}{l}\text { „Przed językoznawcą staje tu problem we- } \\
\text { wnętrznej różnorodności znaczeń pojedyn- } \\
\text { czej formy przypadkowej” (s. 6) }\end{array}$ & $\begin{array}{l}\text { „Problem, jaki przed językoznawcą stawia } \\
\text { opis kategorii przypadka, polega na we- } \\
\text { wnętrznej różnorodności znaczeń w obrębie } \\
\text { pojedynczej kategorii” (s. 10) }\end{array}$ \\
\hline $\begin{array}{l}\text { „Wcześniejsze opracowania były [...] reje- } \\
\text { strem użyć poszczególnych form” (s. 6) }\end{array}$ & $\begin{array}{l}\text { „Część badaczy - podobnie jak większość } \\
\text { gramatyk - ogranicza się do podawania list } \\
\text { poszczególnych użyć” (s. 11) }\end{array}$ \\
\hline $\begin{array}{l}\text { „Druga grupa prac skupia się na poszukiwa- } \\
\text { niu semantycznego wspólnego mianownika } \\
\text { dla wszystkich użyć” (s. 6) }\end{array}$ & $\begin{array}{l}\text { „Przedstawiciele przeciwnej orientacji szuka- } \\
\text { ją zatem semantycznego inwariantu - znacze- } \\
\text { nia wspólnego dla wszystkich użyć” (s. 11) }\end{array}$ \\
\hline $\begin{array}{l}\text { „Na gruncie polskim znakomita próbą w tym } \\
\text { kierunku jest praca Zdzisława Kempfa Próba } \\
\text { teorii przypadków” (s. 6) }\end{array}$ & $\begin{array}{l}\text { „Na gruncie językoznawstwa polskiego } \\
\text { w tym ostatnim nurcie najwyraźniej sytuuje } \\
\text { się [...] Próba teorii przypadków Zdzisława } \\
\text { Kempfa” (s. 11) }\end{array}$ \\
\hline $\begin{array}{l}\text { „Przełomowa dla badań nad przypadkiem stała } \\
\text { się teoria ról semantycznych Ch. Fillmore'a" } \\
\text { (s. 6) }\end{array}$ & $\begin{array}{l}\text { „Przełomowa dla badań nad przypadkiem } \\
\text { okazała się teoria «głębokiego przypadka» } \\
\text { zaproponowana [...] przez Amerykanina } \\
\text { Charlesa Fillmore'a” (s. 11) }\end{array}$ \\
\hline
\end{tabular}




\begin{tabular}{|l|l|}
\hline $\begin{array}{l}\text { „Badacz wysunął postulat wprowadzenia do } \\
\text { organizacji struktur językowych ról seman- } \\
\text { tycznych wyodrębnionych w strukturze głę- } \\
\text { bokiej” (s. 6) }\end{array}$ & $\begin{array}{l}\text { "Postulat wprowadzenia określonej liczby ról } \\
\text { semantycznych jako podstawowych kategorii } \\
\text { organizacji struktur językowych” (s. 11) }\end{array}$ \\
\hline $\begin{array}{l}\text { „sama teoria legła u podstaw kognitywnego } \\
\text { spojrzenia na problem przypadka” (s. 6) }\end{array}$ & $\begin{array}{l}\text { „miał on lec u podstaw teorii wypracowywa- } \\
\text { nej w ramach językoznawstwa kognitywne- } \\
\text { go" (s. 11) }\end{array}$ \\
\hline $\begin{array}{l}\text { „Próbę poszukiwania elementarnego znacze- } \\
\text { nia wszystkich przypadków podjął już w la- } \\
\text { tach 50. XX wieku Adam Heinz” (s. 7) }\end{array}$ & $\begin{array}{l}\text { „Znaczenie czynników pragmatycznych bę- } \\
\text { prac. [...] Autorka dołączyła [...] angielskie } \\
\text { streszczenie pracy Heinza o dopełniaczu } \\
\text { (Heinz 1955)” (s. 13) }\end{array}$ \\
\hline
\end{tabular}

W przypisie 8 na s. 7 Karzarnowicz podaje obie pozycje Heinza wspominane we Wstępie Tabakowskiej i umieszczone w bibliografii książki Rudzkiej-Ostyn. Popełnia tu błąd, bo zamiast „Warszawa 1955” podaje: „Kraków 1955”, zamiast „Kraków 1965”- „Warszawa 1965”.

W części drugiej Wstępu Karzarnowicz tak pisze o stanie badań nad starosłowiańską księgą Dziejów Apostolskich: „Język apostoła nie cieszył się szczególnym zainteresowaniem badaczy, co może trochę dziwić, bo przecież ewangeliarz i apostoł są podstawowymi księgami liturgicznymi, a ich historia przekładu na język staro-cerkiewno-słowiański jest zbliżona i przebiega równolegle" (s. 8). Takie twierdzenie dowodzi braku wiedzy autora, a Bibliografia w książce jest tego najlepszym dowodem - brakuje w niej nazwisk i dzieł badaczy zajmujących się naukowo Apostotem. Wymienię kilka nazwisk: N.A. Mieščerskij, L.P. Žukovskaja, M. Bakker, J.G. van der Tak, A.A. Turilov, P. Peniev, K. Mirčev, Ch. Kodov, A.A. Aleksiejev, D. Bogdanović, B. Velčeva, A. Naumow, I. Dobrev, G.A. Ilj'inskij, A. Kalužniacki, R. Kovačević, S. Kulbakin, H.G. Lunt, I.C. Tarnanidis, I. Christova-Šomova. Ta ostatnia ma w swoim dorobku co najmniej dwadzieścia prac poświęconych wyłącznie Apostołowi, w tym Текстологические особенности Матичиного апостола, zaś w 2004 roku opublikowała ponad ośmiusetstronicową monografię Служебният Апостол в славянската ръкописна традичия (София 2004). Jarosław Karzarnowicz nie zna ani jednego nazwiska, ani jednej pracy wymienionych tu autorów. Nieznany jest mu nawet katalog cyrylickich rękopisów Aleksandra Naumowa, w którym zamieszczono informację również o Śląskim Apostole. Karzarnowicz nie zna też wydawnictw, które regularnie zamieszczają prace badaczy tych zabytków, np. „Palaeobulgariса”, „Кирило-Методиевски студии”, „Acta Palaeoslavica”.

Część trzecia Wstępu - 3. Opis zabytku (s. 9-10) - potwierdza to, co już wcześniej powiedziano: naukową nierzetelność i niekompetencję autora przy określaniu wieku manuskryptu. Karzarnowicz podaje tu, że badany przez niego manuskrypt Apostoła pochodzi z wieku XVI i przytacza swój artykuł zamieszczony w „Slavii Orientalis” (2005, t. 54, nr 1). Jednocześnie w „Biu- 
letynie PTJ" (2007, nr 63) twierdzi, że manuskrypt jest z wieku XV. Jak zatem manuskrypt może być kopią Apostoła Lwowskiego z 1547 roku, co autor też stwierdza? Gubimy się w tym, gubi się sam Karzarnowicz, dopuszczając wiek XV i nawet wiek XVII: „Jak wskazuje zapisek ołówkiem na dole pierwszej karty $X V$ стол, zabytek mógłby pochodzić z tego okresu; pewne datowanie jest jednak utrudnione ze względu na znaczny konserwatyzm językowy" (s. 9). Przyjrzyjmy się jeszcze jednej opinii Karzarnowicza o datowaniu i charakterze Ślaskiego Apostoła.

Otóż na stronach internetowych Nauki Polskiej Karzarnowicz podał, że otrzymany grant BW zużył na „przygotowanie do druku cerkiewnosłowiańskiego rękopisu Apostoła z XV wieku, redakcji wschodniosłowiańskiej (ukraińskiej) własności Biblioteki Śląskiej nr sygn. R 182/III. Praca wykazała cerkiewnosłowiańską ruską redakcję zabytku, opracowanego na podstawie jakiegoś zabytku południowosłowiańskiego (bułgarskiego)". Tym razem mamy więc tezę, że Ślaski Apostoł to jednak nie kopia lwowskiego Apostoła Fiodorowa i że pochodzi z XV wieku.

Ponad dziewięć lat badań Karzarnowicza (zgodnie z informacją na stronach Nauki Polskiej) nie przyniosło mu ustalenia wieku manuskryptu! Tymczasem filigrany na kartach Śląskiego Apostoła są bardzo czytelne i oczywiście stanowią podstawową wskazówkę co do wieku dzieła (zob. il. 3 i 4).

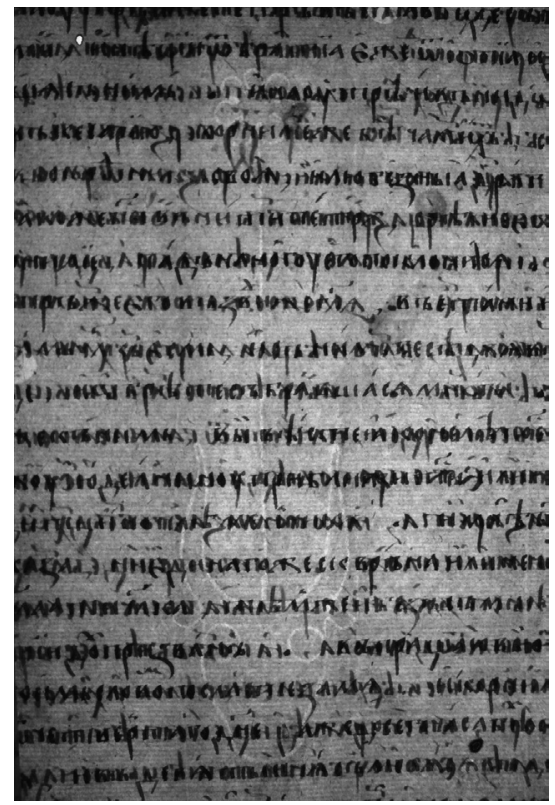

Il. 3. Karta ze Ślaskiego Apostoła $\mathrm{z}$ widocznym filigranem
Briquet, Les filigranes

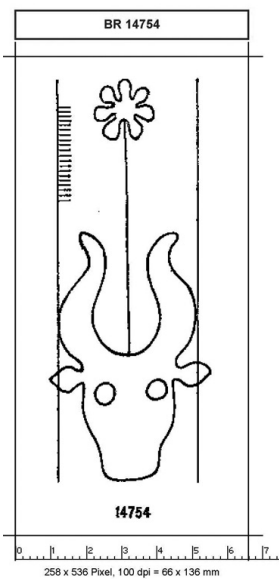

Briquet, Les Filigranes, Nr. 14754 Referenznummer: BR 14754 Abmessungen: $\quad$ w $46 \mathrm{~h} 115$ Datierung(en): $\quad 1430$ Verwendungsort(e): Würzbur

Il. 4. Filigran z katalogu

Briqueta 
Karzarnowicz w swojej książce w ogóle nie bierze pod uwagę filigranów. Zadziwiające jest to, że do opisu manuskryptu Karzarnowiczowi wystarcza otrzymany dziewięć lat temu zdawkowy e-mail z Biblioteki Śląskiej, którego nigdy nie zweryfikował i na który do dziś się powołuje: „W liście otrzymanym przez autora powyższych słów od dyrektora Biblioteki Śląskiej [...] w czerwcu 2002 roku czytamy: «[...] w świetle ostatnio przeprowadzonych przez pracowników lwowskiej Biblioteki Naukowej badań powyższy rękopis jest odpisem z Apostoła wydanego przez Fiodorowa w 1574 roku we Lwowie». Nie udało mi się, niestety, odnaleźć jakiejkolwiek pracy drukowanej poświęconej temu zabytkowi" (s. 9, przypis 15). Ta informacja wystarcza autorowi do opisu manuskryptu, a my nigdzie w książce nie dowiemy się, o jakie najnowsze badania chodzi, o jakich naukowców, o badania czego, na jakiej podstawie i gdzie są te dowody. Odpowiedzi po prostu nie ma, pozostaje dyletanckie, bezpodstawne twierdzenie.

Jarosław Karzarnowicz powtarza zdanie o badaniach pracowników lwowskiej Biblioteki nadal, nie tylko w recenzowanej tu książce, ale i w referacie wygłoszonym na konferencji w Gdańsku w lutym 2009 roku, a następnie wygłoszonym na Ukrainie w 2010 roku i tam opublikowanym ${ }^{4}$. Porównajmy informacje $\mathrm{z}$ recenzowanej książki i z referatów:

\begin{tabular}{|l|l|}
\hline \multicolumn{1}{|c|}{ Recenzowana książka habilitacyjna } & Referat z 2009 roku, artykuł z 2010 roku \\
\hline „Najnowsze badania naukowców ukraiń- & „Badacze ukraińscy widzą w nim kopię \\
skich ze Lwowa dowodzą, że jest on odpi- & lwowskiego Apostoła z 1574 roku [przypis: \\
sem drukowanego Apostoła wykonanego & W liście otrzymanym przeze mnie od dyrek- \\
przez I. Fiodorowa we Lwowie w 1574 roku & tora Biblioteki Śląskiej]” (s. 276) \\
$\begin{array}{l}\text { [przypis: W liście otrzymanym przez autora } \\
\text { powyższych słów od dyrektora Biblioteki }\end{array}$ & \\
Śląskiej]” (s. 9) & \\
\hline
\end{tabular}

Tak więc autor nie wie i nie chce wiedzieć, z jakim zabytkiem ma do czynienia.

W tej samej części trzeciej Wstępu Karzarnowicz z lekceważeniem wskazującym na nierzetelność, a właściwie na brak wiedzy, odnosi się do znaku proweniencyjnego manuskryptu: ,Apostoł pochodzi z księgozbioru niejakiego Pawła Szymańskiego, o czym świadczy ekslibris umieszczony na pierwszej karcie" (s. 9). I to jest cała informacja na ten temat.

${ }^{4}$ Naukovi zapiski, Серія Філологічна, z. 13, Міжкультурна комунікація: мова культура - особистість, Матеріали міжнародної науково-практичної конференції, 22-23 квітня 2010 року, Острог 2010, s. 276. 
A oto sporządzone przeze mnie zdjęcie ekslibrisu z manuskryptu:

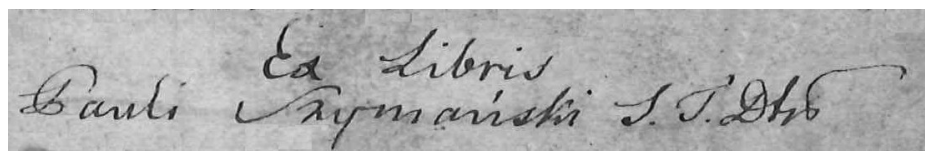

Nawet niespecjalista nie miałby najmniejszej trudności ze zidentyfikowaniem osoby z tego ekslibrisu. „Niejaki Paweł Szymański” to „Ksiądz Paweł Szymański (1782-1852), doktor św. teologii, prałat, dziekan kapituły katedralnej chełmskiej obrządku greckounickiego, b. profesor Pisma św. w b. uniwersytecie Aleksandrowskim i akademii duchownej rzymskokatolickiej warszawskiej"'s.

Rozdziały książki Karzarnowicza poświęcone są poszczególnym przypadkom rzeczownika. W rozdziałach znajdziemy liczne błędy gramatyczne i dywagacje semantyczne, z którymi nie można się zgodzić ${ }^{6}$.

W rozdziale 1. Funkcjonowanie $i$ użycie form mianownika $i$ wołacza, w części 1.4. Formy nominativu Karzarnowicz o deklinacji spółgłoskowej rzeczowników pisze: ,[...] reprezentowana jest w zabytku przez nieliczną grupę rzeczowników z morfemami rozszerzającymi -en- i -ec-” (s. 27). Twierdzenie takie zawiera błąd, ponieważ nie mamy tu w żadnym razie do czynienia $\mathrm{z}$ „morfemami rozszerzającymi” - to w ogóle nie są morfemy, ale część rdzenia podstawy $\mathrm{z} * \mathrm{n} \mathrm{i} *_{\mathrm{s}}$.

W części 1.5. Użycie i formy wołacza w zdaniu, „w ГАоуБнна вогатьства и гаршстн н разогима вжіа" (s. 30) Karzarnowicz podkreśla wyraz, który według niego „funkcjonuje jako forma bezpośredniego zwrotu do adresata”. Tymczasem jest to przecież retoryczny wykrzyknik.

W rozdziale 2. Użycie i formy dopetniacza, w części 2.5. Formy dopetniacza autor podaje rzeczowniki ,-*ja-tematowe”, które jego zdaniem w G sing. „mogą przybrać końcówkę -н:

$18 \mathrm{~b} / 4$ в'Хर въСА четверонога земАн

25b/1 даже АО поси БАнн Земкн

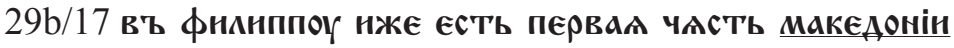

152a/18-19 Аа БОУАЕТЕ СЪВРЬШЕнН и сПАЪНЕнН ВСАКОН ВОЛН БЖін" (s. 58-59).

5 J. Łoski, Ksiądz Pawet Szymański (1782-1852), http://unici.pl/content/view/88 [dostęp: 7.12.2010].

${ }^{6}$ Bardzo dziękuję panu prof. Vadimowi B. Krys'ko z Rosyjskiej Akademii Nauk, który zechciał podzielić się ze mną dostrzeżonymi błędami gramatycznymi, semantycznymi i literowymi w tekście książki Karzarnowicza. 
Jest to błędne twierdzenie - w powyższych przykładach nie mamy do czynienia z dopełniaczem, ale ze zwykłym celownikiem przyrzeczownikowym (dodatkowo w ostatnim zdaniu niewłaściwie podzielono wyrazy: zamiast и сплънени powinno być: нсплъненн. Równie niewłaściwy podział wyrazów spotkamy też na dalszych stronach, np. 142 - jest: словоданію, а powinno bус́: слово Аанію.

Na kolejnej stronie tej samej części trzeciej rozdziału drugiego Karzarnowicz pisze błędnie: „Rzeczownik вратіа ma niekiedy znaczenie liczby mnogiej (mianownik), niekiedy zaś - to dopełniacz liczby pojedynczej (rzeczownik zbiorowy): 12b/14-15 пр॰ ${ }^{\circ}$ ка вамь въЗАвнгнеть [...] БЪ вашь

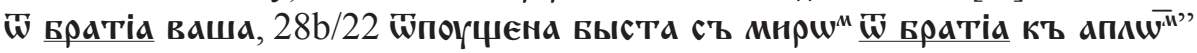
(s. 59).

Otóż вратia we wszystkich kontekstach, niezależnie od przypadka, to zawsze forma liczby pojedynczej rzeczownika zbiorowego. Inna sprawa, że wtórnie może się tu rozwijać forma liczby mnogiej, np. вратіамь (s. 78).

W rozdziale trzecim książki - 3.3. Użycie i formy celownika - Karzarnowicz pisze nienaukowo i naiwnie: ,celownik, na gruncie słowiańskim dobrze zachowany, zbliża się semantycznie do dopełniacza w jego znaczeniach konkretnych. Na przykład w niektórych gwarach północno-wschodniej i wschodniej Polski mówi się wręcz powiedzieć coś dla kogoś zamiast komuś [...]. Osobiście znam te formy z Mazur i północno-wschodniego zakątka Kurpiów [...]”, (s. 62).

Doprawdy zamiast powoływać się na „osobistą znajomość form” autor powinien wykazać znajomość polskiej dialektologii, polskich gwar, a wtedy nie popełniłby merytorycznego błędu w uzasadnianiu powodu użycia konstrukcji „dla + dopełniacz” - nie mamy tu przecież do czynienia z czymś takim jak „zbliżanie się semantyczne do dopełniacza” przez celownik. Chodzi tu o znaną kwestię dywergencji językowej pogranicza. Halina Karaś pisze: „Adwerbalna konstrukcja $d l a+$ D. w funkcji celownika przyczasownikowego występuje nie tylko w gwarach północno-wschodnich, lecz również w odmianie regionalnej, w języku inteligencji białostockiej. W opracowaniach językoznawczych wymieniana jest jako wyrazisty przykład jednego z regionalizmów białostockich. W upowszechnieniu się tej konstrukcji na obszarach pogranicza polsko-wschodniosłowiańskiego można widzieć przykład dywergencji językowej, czyli tendencji do odpodobnienia spokrewnionych ze sobą języków"7.

W tym samym rozdziale trzecim, w jego kolejnej części - 3.4. Dativus jako okolicznik - Karzarnowicz uznaje za okolicznik jedynie „okoliczności, przyczyny i motywy czyjegoś postępowania oraz sposób w jaki czynność za-

${ }^{7}$ Gwary polskie. Przewodnik multimedialny, red. H. Karaś, http://www.gwarypolskie.uw. edu.pl/index.php?option=com_content\&task=view\&id=189\&Itemid=58 [dostęp: 20.03 .2011$]$. 
chodzi” (s. 76). Pisze dalej: „Znaczenie okolicznikowe ma najczęściej konstrukcja przyimkowa no + dativus". A więc autor dostrzega jedynie okolicznik sposobu, bo nie ma mowy w tym rozdziale o datiwie jako okoliczniku miejsca, jak w słowach: домовн, долоу. Znaczenie okolicznika miejsca to dla Karzarnowicza oddzielna część rozdziału nazwana 3.2. Znaczenie allatywne dativu (s. 72).

Merytoryczną ignorancję widzimy we wniosku, do którego autor dochodzi, porównując wyrażenia падє Aonor i падоX на земкн. Ponieważ w zwrotach tych czasownik пастн - „upaść” - wystąpił raz bez przyimka - падє Aолоу - a raz z przyimkiem - паAОX на земмн - Karzarnowicz, nie dostrzegając dwóch znaczeń - „kierunek upadku” i „miejsce upadku” - podaje swoją etymologię czasownika „upaść”: „Przykład ten potwierdza, że nie zawsze czasownik падатн traktowany był jak czasownik ruchu. Wszystko wskazuje, że sem ruchu rozwinął się w nim później” (s. 73). Taki wniosek doprawdy zasługuje na miano pychy silącej się na naukowość. Najwyraźniej autor nie spotkał się nigdy ze zdaniem typu: „невреженнем свонм со сводҮ паде Аолу na землю" - mamy tu jasno rozdzielone: kierunek ruchu - AONY - i miejsce końca ruchu - нa земмю ${ }^{8}$.

W książce Karzarnowicza proste wyrazy zdają się stanowić semantyczny problem dla autora: глава жен' (s. 80) to według niego przykład do podrozdziału 3.5.1. Dativus possesivus (s. 79), ale gramatycznie identyczne wyrażenie начахьннкъ съьороя (s. 81) to przykład do innego podrozdziału, mianowicie do 3.5.2. Dativus punktu odniesienia (s. 80).

W rozdziale czwartym, w części 4.4. Formy deklinacyjne biernika. Formy dopetniacza w bierniku rzeczowników, zaimków i przymiotników czytamy:

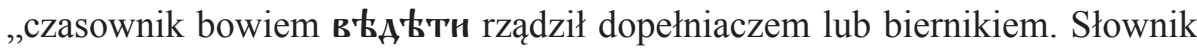
scs. Cejtlin i Večerki [przypis: Por. Старославянский словарь..., s. 164] nie określa rządu tego czasownika, choć cytowane tam przykłady wskazują na rząd dopełniaczowy [...]" (s. 97-98). Otóż zupełnie niczym nie jest potwierdzone rządzenie dopełniaczem przez czasownik в \$А $\mathbf{k T н - С т а р о с л а в я н с к и и ̆ ~ с л о - ~}$ варь, na który powołuje się Karzarnowicz, nie podaje ani jednego przykładu z dopełniaczem!

${ }^{8}$ Zdanie zaczerpnięte z tekstu „Повесть о начале зачатия и поставлении первыя древныя церкве святаго Николая Чудотворца, что на Пенье, како и кем доброхотных жителей и в которыя лета нача созидатися, и о явлении и написании и пренесения честнага образа пресвятыя Богородицы, Одигитрия нарицаемыя, Феодоровския и о создании, устроении и украшении вторыя каменныя церкве во имя Ея пресвятыя Богородицы Феодоровския, и потом о чудесах Ея, бываемых от онага образа пресвятыя Владычицы нашея Богородицы и Приснодевы Марии, купно же и летопись сея церкви" dostępnego online: http:// ru.wikipedia.org [dostęp: 6.12.2010] (hasło Фёдоровская церкковь (Ярославль)). 
W tym samym podrozdziale 4.4., na s. 98 znajdujemy naiwne rozważania o słowie Aor/X'b, a na s. 99 i 100 równie naiwne o formach typu въ мтреє твюю. Mogłyby one mieć bardziej naukowy charakter, gdyby autor skorzystał z klasycznych i współczesnych prac o kategorii żywotności. Niestety Karzarnowicz żadnych prac na ten temat nie zna.

Zdarza się w recenzowanej książce, że autor zupełnie nie rozumie zdania z manuskryptu. Tak jest na przykład ze zdaniem cytowanym na s. 102: помннатн томУ вйочьстіа и прароднтелен его вњры. O tym zdaniu Karzarnowicz pisze, że rzeczownik żywotny прароднтелен ,ma w bierniku liczby mnogiej formę dopełniacza". A przecież w zdaniu tym rzeczownik прароднтелен nie stoi w związku z czasownikiem помннатн, ale z rzeczownikiem в фры i nie jest formą biernika, ale dopełniacza. Poza tym czasownik помннаTн rządzi dopełniaczem, a nie biernikiem, jak podaje Karzarnowicz.

Kolejny błędy niezrozumienia zdania z manuskryptu mamy na s. 102-103. Tutaj Karzarnowicz ilustruje formę dopełniacza w bierniku liczby mnogiej

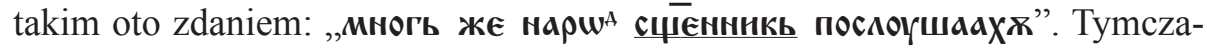
sem mamy tu zwykły dopełniacz przy czasowniku послоушатн, a nie biernik z formą dopełniacza! Na tej samej stronie 103, w zdaniu, „швр іољАен соүщінхь” autor ponownie dostrzega biernik z formą dopełniacza zamiast zwykłego dopełniacza, który jest możliwy z przyimkiem 3a. W kolejnym zdaniu raz jeszcze widzi biernik z formą dopełniacza zamiast zwykłego dopełniacza z czasownikiem посњтнтн: „єже посњщатн снрых и вдовнць”.

Przejdźmy do rozdziału szóstego. Tutaj, w podrozdziale 6.5. Formy miejscownika Karzarnowicz twierdzi, że rzeczowniki „,нце, Ар њво mogą mieć formy miejscownika wg deklinacji męskiej -*o" (s. 142). Takie sformułowanie wywołuje niewłaściwe wrażenie, że formy te należą do odmiany spółgłoskowej, a tak nie jest.

Na s. 144 równie niewłaściwie został zaszeregowany rzeczownik w zdaniu: „w немже молюс въ южа czownik za rzeczownik rodzaju żeńskiego i zakwalifikował go do „deklinacji o temacie na -*a//-*ja”. Tymczasem jest to rzeczownik rodzaju nijakiego i należy do deklinacji na -*o: оүжє/южє.

Na tej samej s. 144, w przypisie 75 czytamy informację, że rzeczownik wystąpił ,trzykrotnie w miejscowniku liczby pojedynczej, zawsze z tą samą końcówką -ax’””. Tymczasem jest oczywiste, że taka końcówka w liczbie pojedynczej nigdy nie występuje.

Niesłychanie nierzetelnie sporządzona jest - mająca niewiele wspólnego z przypisami i licząca zaledwie 55 pozycji - Bibliografia w książce Karzarnowicza (s. 149-151). W jej spisie nie znajdziemy 27 prac występujących w przypisach książki, z kolei w przypisach nie znajdziemy 20 prac ujętych w Biblio- 
grafii. Listę tych prac podaję w oryginalnym zapisie z książki Karzarnowicza, zachowując brak konsekwencji w sposobie zapisu bibliograficznego.

A. W Bibliografii nie znajdziemy następujących pozycji, które są w przypisach:

1. J. Apresjan, Semantyka leksykalna. Synonimiczne środki języka, Ossolineum 1980, (jest w przypisie 5 i 7, s. 6);

2. Żywoty Konstantyna i Metodego (obszerne). Przełożyt i przypisami opatrzył Tadeusz Lehr-Spławiński, Warszawa 2000 (jest w przypisie 9, s. 8);

3. Г. А. Воскресенский, Древний славянский перевод апостола и его судьбы до XV века, Москва 1879 (przyрis 10, s. 8);

4. L. Moszyński, Jaki Apostol - aprakos przettumaczyli i zredagowali Nauczyciele Stowian Konstanty i Metody przed przybyciem na Morawy, Z polskich studiów slawistycznych, seria 9 Językoznawstwo. Prace na XII Międzynarodowy Kongres Slawistów, Warszawa 1998 (przypis 11, s. 8);

5. O. Nedeljković, Problem strukturnih redakcija staroslavenskog apostola, Slovo 22, Zagreb 1972 (przypis 13, s. 8; tu opuszczono słowo „prijevoda” i nazwę księgi „Apostola” zapisano małą literą zamiast dużą);

6. L. Moszyński, Fragmenty psałterzowe Apostoła Enińskiego wobec tzw. Psatterza Synajskiego, [w:] Константин Кирил Философ. Доклади от симпозиума посветен на 1100 годшнината от смрътта му, ред. Б. Ангелов, Sofia 1971 (przypis 14, s. 9);

7. Библия. Книги священного писания Ветхого и Нового Завета канонические в русском переводе с параллельньми местами, Москва 1968 (przypis 16, s. 10);

8. Karzarnowicz J. Cerkiewnosłowiański rękopiśmienny Apostoł z Biblioteki Ślaskiej, Slavia Orientalis, LIII, z. 12004 (przypis 17, s. 10; notabene Karzarnowicz podaje dwa różne roczniki Slavii dla swojego powyższego artykułu: w przypisie w książce habilitacyjnej: Slavia Orientalis, LIII, z. 12004 , a w przypisie do referatu o liczebniku w Ślaskim Apostole, opublikowanego na Ukrainie w 2010 roku podaje: Slavia Orientalis, LII, nr 2, 2003);

9. Nestle-Aland, Novum Testamentum Graece et Latina, Introduction, Stuttgart 1984 (przypis 18, s. 14);

10. Biblia Tysiąclecia (przypis 19, s. 14; w tym przypisie podano też nieistniejącą nazwę Biblii: Biblia rosyjska z 1968 roku);

11. B. Rudzka-Ostyn, O strukturze dopetniacza, [w:] idem, Z rozważań..., s. 181-199. (przypis 21, s. 34; tu podano błędny tytuł, ponieważ poprawnie brzmi on: Struktura kategorii dopetniacza na przykładzie języka polskiego (1994));

12. R. Popowski, Wielki słownik grecko-polski Nowego testamentu, Warszawa 1995 (przypis 25, s. 48); 
13. S. Szober, Gramatyka języka polskiego, wyd. 5, Warszawa 1959 (przypis 30 , s. 62);

14. Старославянский словарь по рукописям $X-X 1$ веков, под ред. P.М. Цейтлин, Р. Вечерки, Э. Благовой, Москва 1994 (przypis 35, s. 64);

15. J. Kuryłowicz, The Inflectional Categories of Indo-Eurepean, Heidelberg 1964 (przypis 36, s. 65);

16. А. Белић, Историја српског језика. Фонетика. Речи са деклионацијом. Речи са конјугаиијом, Нови Сад 1999 (przyрis 39, s. 68);

17. M. Brodowska (Honowska), O dzierżawczej funkcji celownika, Biuletyn PTJ, 12, 1953 (przypis 43, s. 79);

18. А. Б. Правдин, К вопросу о праславянских значениях дательного падежа, Вопросы языкознания, 6, 1957 (przypis 49, s. 86);

19. L. A. Janda, Koncepcja przypadka i czasu w językach stowiańskich, Kraków 2004 (przypis 53, s. 95);

20. Г. Дьяченко, Полный иеерковно-славАнский словарь, Москва 2004 (przypis 56, s. 98);

21. С. Новаковић, Примери књижевности и језика старога и српско словенскога, Belgrad 1904 (przypis 67, s. 118);

22. А. Белић, Изабрана дела, т. 4, Историја српског језика. Фонетика речи са деклинаиијом, Белград 1999 (przypis 68, s. 126);

23. T. P. Krzeszowski, Aksjologiczne aspekty metafor, [w:] Językoznawstwo kognitywne. Wybór tekstów, pod red. W. Kubińskiego, R. Kalisza, E. Modrzejewskiej, Gdańsk 1998 (przypis 70, s. 131);

24. G. Lakoff, The Invarians Hypothesis: Is Abstract Reason Based on Image Schemas, Cognitive Linguistics 1 (przypis 70, s. 131);

25. J. Maćkiewicz, Stowo o słowie. Potoczna wiedza o języku, Gdańsk 1999 (przypis 71, s. 132);

26. M. Didiakin-Leeming, Fleksja ukraińska w leksykonie Pamby Beryn$d y$, Ossolineum 1969 (przypis 73, s. 142);

27. T. Jasińska-Socha, System fleksyjny staro-biatoruskich zabytków II potowy XVI wieku, Ossolineum 1979 (przypis 70, s. 142).

B. W przypisach nie znajdziemy następujących pozycji, które są w $B i$ bliografi:

1. Arsenijević N., Akuzativ s predlogom za u savremenom srpskom jeziku; Zbornik za filologiju i lingwistiku, Novi Sad, XLVI/1, 2003 (część I);

2. Arsenijević N., Akuzativ s predlogom za u savremenom srpskom jeziku; Zbornik za filologiju i lingwistiku, Novi Sad, XLVI/2, 2003 (część II);

3. Fillmore Ch., The Case for Case, Universals in Linguistic Theory, New York 1968 (o nierzetelności samego zapisu - poniżej); 
4. Fillmore Ch., Some problems for Case Grammar, Georgetown 1971 (o nierzetelności również i tego zapisu - poniżej);

5. Gerodes S., Старославянские предлоги, [w:] Исследования по синтаксису старославянского языка, Прага 1963 (różnorodność grafiki w tym zapisie objaśniam poniżej, w pkt C1);

6. Ivić M., Značenija srpskohrvatskog instrumentala i njihov razvoj sintaksičko-semantička studija), Beograd 1954;

7. Ivić M., Oboczne użycie dopetniacza i narzędnika $w$ funkcji rezultatywnej [w:] idem, Z badań nad językami Jugosławii, Warszawa 1961;

8. Kempf Z., Sposoby wyrażania funkcji esywnej w jezyku polskim, Rozprawy Komisji Językowej Łódzkiego Towarzystwa Naukowego, t. XVI, Łódź 1970 ;

9. Kempf Z., O sposobach językowego wyrażania przyczyny, Prace Filologiczne 22 (tu brak roku - 1972);

10. Kempf Z., Próba teorii przypadków, Opole 1978 (tu brak zaznaczenia, że to część I; notabene w 2007 roku wyszła część II z tym samym tytułem);

11. Łoś J., Funkcje narzędnika w języku polskim, Kraków 1904;

12. Miloradović S., Iskazivanja posesivnosti predlogom od u srpskim narodnim govorima, Slavia Meridionalis, 6, 2006, Warszawa;

13. Mrázek R., К вопросу о функциях беспредложного творительного падежа, Sborník Prací Filosofícke Fákulty Brněnske iniversity, řada jazykovedna roč. 9, Brno 1960;

14. Mrázek R., Дательный падеж в старославянском языке, [w:] Исследования по синтаксису старославянского языка, Прага 1963;

15. Mrázek R., Синтаксис русского творительного (структурно сравнительное исследование), Прага 1964;

16. Micewicz T., Uniwersalia semantyczne w opisie przypadków Ch. J. FilImore'a, Kwartalnik Neofilologiczny 1973, z. 3;

17. Večerka R., Ke konkurencii adnominalního genitivu a adjektiva, Sbornik praci Filosoficke Fakulty Brnĕnske iniversity, řada jazykovedna, roč. 6, Brno 1957;

18. Večerka R., Střidení zaporoveho genitivu se zaporowym akusativem ve staroslověnštině; „Studie ze slovanske jazykovědy”, Praga 1958;

19. Večerka R., Синтаксис беспредложного родительного падежа в старославянском языке, [w:] Исследования по синтаксису старославянского языка, Прага 1963;

20. Večerka R., Genitiv data v staroslověnštině, „Slavia”, roč. 26, z. 1, 1975.

W książce Karzarnowicza są jeszcze inne dowody nierzetelnego sporządzenia Bibliografii i przypisów, np.: 
- różny zapis tej samej pozycji (inny w przypisie i inny w Bibliografii) oraz łacińska czcionka nazwiska autora i jednocześnie rosyjska czcionka tytułu pracy, np. w przypisie 69, s. 128: J. Bauer, Беспредложный локатив в старославянском языке, [w:] Исследования по синтаксису старославянского языка, Praga 1963, a w Bibliografii (s. 149): Bauer J., Беспредложный локатив в старославянском языке, [w:] Исследования по синтаксису старославянского языка, Прага 1963. Tymczasem powinno być: Я. Бауер, Беспредложный локатив в старославянском языке, [w:] Исследования по синтаксису старославянского языка, Прага 1963. Nietrudno dociec, skąd mógł się wziąc tak dziwny graficznie zapis w Bibliografii Karzarnowicza. Otóż w internecie jest dostępne online, w formacie PDF, słoweńskie czasopismo „Jezikoslovni zapiski, Glasilo Inštituta za slovenski jezik Frana Ramovša" (2008, 14.2) - chodzi o plik URN_NBN_SI_doc-VNJIJPVG.pdf na stronie www.dlib.si. To tutaj właśnie, na s. 58, spotykamy słoweński styl zapisu pozycji bibliograficznej, którą skopiował do swojej Bibliografii Karzarnowicz. W słoweńskim tekście nazwisko autora zapisano łacinką, a tytuł jego pracy pozostawiono w języku (alfabecie) pracy, czyli po rosyjsku. Tak skopiował to Karzarnowicz. Gdyby dzieło miał w ręku, zapisałby je zgodnie z oryginałem i w konwencji polskiej, a nie mieszaniną graficzną. Taka sama sytuacja ma miejsce przy nazwisku Bauerova M. (s. 149);

- zapis pozycji Fillmore'a na s. 149 brzmi: Fillmore Ch., The Case for Case, Universals in Linguistic Theory, New York 1968. Tymczasem praca Fillmore'a nie jest oddzielną publikacją, jak sugeruje zapis w Bibliografii Karzarnowicza, ale znajduje się w książce Universals in linguistic theory, red. E.W. Bach, R.T. Harms;

- dokładnie to samo widzimy przy drugim zapisie pracy tego samego autora: Fillmore Ch., Some problems for Case Grammar, Georgetown 1971. Z tego zapisu wynika, że chodzi o książkę Fillmore'a. Tymczasem praca Fillmore'a znajduje się w książce: Report of the Twenty-Second Annual Round Table Meeting on Linguistics and Language Studies, wyd. R.J. O'Brien, Washington 1971. Powyższa nierzetelność wynika stąd, że J. Karzarnowicz wykorzystał pracę Brygidy Rudzkiej-Ostyn, Z rozważań nad kategoria przypadka (przeł., red. Elżbieta Tabakowska, Kraków 2000), ale zrobił to w nieuczciwy sposób książka Rudzkiej-Ostyn jest polskim tłumaczeniem z języka angielskiego, a więc i układ zapisów w bibliografii jest angielski. Karzarnowicz wybrał pozycje z bibliografii zawartej w książce Rudzkiej-Ostyn i umieścił je w swojej Bibliografii (nie w przypisach!). Źle odczytał jednak sposób zapisu bibliograficznego i stąd błędy w zapisach w jego Bibliografii. Rudzka-Ostyn podaje jako oddzielne pozycje i artykuł, i dzieło zbiorowe, w którym artykuł się znajduje. Ta wskazówka jest umieszczona oczywiście przy autorze artykułu, ale Karzar- 
nowicz nie umiał jej odczytać. W przypadku Fillmore'a zapis w bibliografii Rudzkiej-Ostyn wygląda następująco: Fillmore, Charles. 1968. „The case for case". W: Emmon Bach i Robert T. Harms, wyd., 1-88. Żeby tak podaną pozycję zapisać według polskich standardów bibliograficznych, należało odnaleźć w bibliografii Rudzkiej-Ostyn Emmona Bacha i Roberta T. Harmsa, ponieważ to w książce pod ich redakcją, na s. 1-88, znajduje się praca Fillmore'a. I tego właśnie Karzarnowicz nie potrafił odczytać właściwie;

- w Bibliografii Karzarnowicz umieścił następującą pozycję: Bartula Cz., Związi czasownika $z$ dopetnieniem $w$ najstarszych tekstach staro-cerkiewnosłowiańskich, Kraków 1964. Taka pozycja w ogóle nie istnieje (!), a Czesław Bartula napisał Zwiazki czasownika z dopetnieniem w najstarszych zabytkach języka staro-cerkiewno-stowiańskiego (redaktor naukowy tomu - Tadeusz Lehr-Spławiński, wydawnictwo Ossolineum, Wrocław-Warszawa-Kraków 1964);

- książka: A. Heinz, System przypadkowy języka polskiego, Warszawa 1965, w przypisie 8 na s. 7 jest wydana w Warszawie, a w Bibliografii - w Krakowie!;

- książka: A. Heinz, Genetivus w indoeuropejskim systemie przypadkowym, Kraków 1955, w przypisie na s. 7 jest wydana w Krakowie, a w Bibliografii - w Warszawie!;

- Vatroslav Jagić to w przypisie 12 na s. 8: W. Jagić, Zum altkischenslawischen Apostolus, I-III, Wien 1919, a w Bibliografii: Jagić V., Zum Altkischenslawischen Apostolus, cz. 1-3, Wien 1919. Oczywiście przymiotnik w przypisie i w Bibliografii ma ten sam błąd -kischen- zamiast -kirchen-.

Kolejna część książki Karzarnowicza, Indeks form rzeczowników (s. 152-177) niestety również zaskakuje swoją nierzetelnością i merytorycznymi błędami (zapisy podaję w pisowni oryginalnej):

- bardzo wielu form podanych w Indeksie nie znajdziemy na tych stronach książki J. Karzarnowicza, na których według Indeksu mają one występować. Na samej tylko stronie 152 następujące wyrazy nie znajdują się na wskazanych

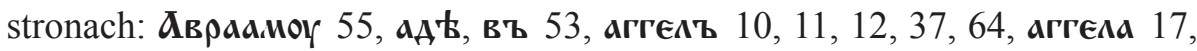

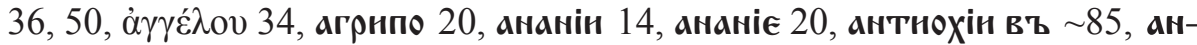
тнхрнстъ 14, аполось о $\sim 92$. Tak więc na dziewiętnaście form Indeksu tylko dwie są we wskazanych miejscach, siedemnastu nie ma!;

- do Indeksu nie weszło wiele wyrazów przytaczanych w treści książki. Nie znajdziemy w nim na przykład następujących form wyrazów: raкwвь, ішанн (w książce s. 16), главахь, власъ, главы, мюдех, гнЊв, въкь (s. 17),

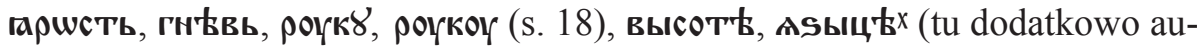
tor zapisał słowo niezgodnie z oryginałem: w oryginale jest 3 , a nie s), ішсін, тавнга, серна (s. 19), пъжь (s. 105), въ югаь (s. 141), о гадени (s. 142);

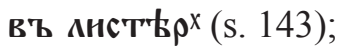


- autor nie trzyma się własnej decyzji o zasadzie prezentowania form w Indeksie. Zapewnia mianowicie, że „centrum gniazda” to „,nominativus singularis rzeczownika. Jeśli jest on równy formie accusativu, to centrum może być też i ta forma" (s. 152). Tymczasem wyrazem hasłowym bywa w Indeksie również nominativus pluralis, np. чюдєса - n. pl. (s. 176), посланннци - n. pl. (s. 167);

- kolejnymi brakami w Indeksie są rozbieżności zapisu form - inny zapis mamy w tekście pracy, inny w Indeksie, a żaden z nich nie zgadza się z oryginałem Ślaskiego Apostoła! Ponadto Karzarnowicz podaje błędnie strony manuskryptu. Oto kilka przykładów:

\begin{tabular}{|c|c|c|c|c|c|c|}
\hline Zapis w książce & Strona & $\begin{array}{c}\text { Zapis } \\
\text { w Indeksie }\end{array}$ & Strona & $\begin{array}{c}\text { Zapis } \\
\text { w manuskrypcie }\end{array}$ & $\begin{array}{l}\text { Strona } \\
\text { według } \\
\text { J.K. }\end{array}$ & $\begin{array}{c}\text { Strona } \\
\text { W manu- } \\
\text { skrypcie }\end{array}$ \\
\hline Фнанппь & 16 & Фнкнппв & 175 & 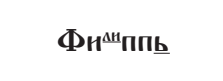 & $\begin{array}{c}1 \mathrm{~b} / \\
17-21\end{array}$ & \\
\hline SHNOT'b & 16 & зинот"ъ & 160 & SнмоT'b & $\begin{array}{c}1 \mathrm{~b} / \\
17-21\end{array}$ & \\
\hline въськооувиіца & 16 & въськооувінца & 156 & въсько0у/вїнца & $51 \mathrm{a} / 3$ & \\
\hline оувніца & 16 & оувінца & 174 & огвїнца & $\begin{array}{c}62 \mathrm{~b} / \\
7-9\end{array}$ & $\begin{array}{c}63 \mathrm{~b} / \\
6-9\end{array}$ \\
\hline АЕЖЕОГЧнТЕАЕ & 16 & Аъжеоучителе & 162 & АьЖЕОГЧИТЕАЕ & $65 \mathrm{a} / 8$ & $66 \mathrm{a} / 8$ \\
\hline кұпръ & 17 & кпำ $\mathbf{b}^{*}$ & 162 & кұпръ & $\begin{array}{c}48 \mathrm{~b} / \\
20-21\end{array}$ & \\
\hline wвкасть & 17 & овмасть & 165 & wББасть & $\begin{array}{c}76 \mathrm{~b} / \\
19\end{array}$ & $\begin{array}{c}78 \mathrm{~b} / \\
18\end{array}$ \\
\hline cㅍa & 18 & colfad & 172 & cxAd & $\begin{array}{l}183 \mathrm{~b} / \\
13-14\end{array}$ & $\begin{array}{l}184 \mathrm{~b} / \\
13-14\end{array}$ \\
\hline мшисн & 18 & мwیгсн & 164 & мшисн & $\begin{array}{c}11 \mathrm{~b} / \\
20\end{array}$ & \\
\hline wетавленiе & 19 & оставленіє & 165 & wеттавленїє & $\begin{array}{c}24 \mathrm{~b} / \\
26\end{array}$ & $\begin{array}{c}24 \mathrm{~b} / \\
25-26\end{array}$ \\
\hline
\end{tabular}

* Ta forma nie ma w Indeksie wyrazu hasłowego.

Z powyższego zestawienia wynika, że na jednej tylko stronie książki (s. 16) mamy aż pięć błędnie zapisanych wyrazów analizowanych przez Karzarnowicza, zaś wszystkie dziesięć przytoczonych tu wyrazów mają inny zapis w tekście książki i inny w Indeksie. Do tego dodać można błędne podawanie przez Karzarnowicza lokalizacji wyrazów w oryginale - tak jest w pięciu na dziesięć przytoczonych przykładów;

- w Indeksie mamy błędną kolejność alfabetyczną wyrazów hasłowych. Na przykład hasło врат'ъ znajduje się przed вратолювіє (s. 153), сънъ 
przed соломонъ, съто przed стопа (s.171), прншькьць przed прншествіє (s. 167-168), сҺть przed съБлазнъ (s. 172), съвҺтЪ przed съврьстннца (s. 172);

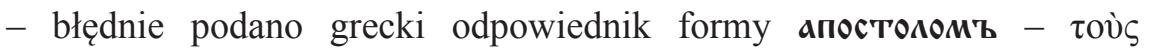

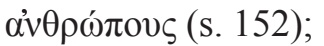

- błędnie utworzono, błędnie przyporządkowano do haseł bądź z błędami zapisano hasła dla wielu form, nр.: влагов Тствованіа - podano pod hasłem влаговЊстваніе (s. 153), галатін - pod глаті (s. 156), жндовомъ pod жндовннь (s. 159), Братен pod Брат” zamiast pod вратіа, до зорен nie odnosi się do зорга (s. 160), ale wyłącznie do зорь, forma чръвмн (s. 176) w ogóle nie ma wyrazu hasłowego;

- wielokrotnie błędnie określono rodzaj gramatyczny, np.: AожAє (s. 157)

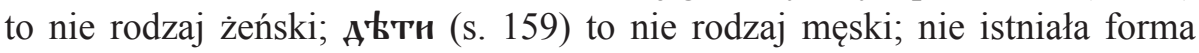
пъжеБратіє, rodzaj nijaki, ale jedynie forma иъжевратіґ - rodzaj żeński; постькь (s. 167) to nie rodzaj męski, ale żeński; юнота (s. 177) to nie rodzaj żeński, ale męski;

- występują liczne błędy w zapisach oryginalnych wyrazów z manuskryptów staro-cerkiewno-słowiańskich: копрнниню (s. 29), нАниожертвъ (s. 60), Поскуошати (s. 103), Аъ АОмУ (s. 141), нак АіЕ, неПарвАа (s. 164), отрокаъ (s. 165), пармнъ (s. 166), прорХоръ, разсжаждеміа (s. 168) itd.;

- błędnie, i to w całej książce, przekazywany jest grafem manuskryptu ï jako i, a połączenie ïa, ïe jako, iє.

Niestety wszystkie wykazane powyżej błędy i nieścisłości w Indeksie form rzeczowników powodują, że nie spełnia on funkcji narzędzia do przeglądania wyrazów manuskryptu omawianych w książce. Jest więc bezużyteczny $-\mathrm{z}$ jednej strony niezliczone rozbieżności w zapisie form rzeczowników u Karzarnowicza i w manuskrypcie czynią Indeks bezużytecznym materiałowo, z drugiej - rozbieżności w liczbie i zapisie form użytych w tekście i ujętych w Indeksie czynią go bezużytecznym nawet jako narzędzie do studiowania książki.

Nierzetelność przytaczania przez Karzarnowicza wyrazów z manuskryptu Apostoła nie przeszkadza mu zachwalać swej pracy jako nowatorskiej. Pisze on: „Niniejsza rozprawa ma w pewnym sensie charakter nowatorski, ponieważ przedmiotem analizy jest w niej materiał nieopisanego dotychczas apostoła pełnego ze zbiorów polskich. Praca [...] włącza materiał tego zabytku do szczegółowych badań fleksyjnych i syntaktycznych języka cerkiewnosłowiańskiego" (s. 9). 
Niestety należy przestrzec przed włączaniem „do szczegółowych badań” materiału zabytku z książki Jarosława Karzarnowicza ze względu na zbyt poważne uchybienia i błędy, nierzetelne traktowanie danych, wiedzy, nauki.

Tyle błędów i nierzetelności wskazuje, że mamy do czynienia z nieporozumieniem naukowym - książka w tej postaci w ogóle nie powinna być wydrukowana. 